\title{
Anatomical modifications of Butia capitata propagated under colored shade nets
}

\author{
BÁRBARA N.S. COSTA ${ }^{1}$, IRTON J.S. COSTA ${ }^{1}$, GENAINA A. DE SOUZA ${ }^{2}$, DALILHIA N. DOS \\ SANTOS $^{1}$, FLÁVIA A. DA SILVEIRA ${ }^{1}$, EVALDO T. DE MELO ${ }^{1}$, ADALVAN D. MARTINS ${ }^{1}$, \\ MOACIR PASQUAL ${ }^{1}$, TESFAHUN A. SETOTAW ${ }^{1}$ and FILIPE A. RODRIGUES ${ }^{1}$
}

\author{
${ }^{1}$ Departamento de Agricultura, Universidade Federal de Lavras, Av. Doutor Sylvio \\ Menicucci, 1001, Kennedy, 37200-000 Lavras, MG, Brazil \\ ${ }^{2}$ Departamento de Biologia Vegetal, Universidade Federal de Viçosa, Av. Peter Henry \\ Rolfs, s/n, Campus Universitário, 36570-000 Viçosa, MG, Brazil
}

Manuscript receive on July 4, 2017; accepted for publication on May 18, 2018

\begin{abstract}
The jelly palm plant [Butia capitata (Martius) Beccari] is a native palm of the Cerrado biome used for many purposes in northern Minas Gerais State, Brazil. Dormancy is common in palm seeds, resulting in slow and uneven germination that may take years to complete. Modification in the growth pattern, anatomical parameters, physiological and biochemical characteristics of the plant can be verified due to changes in the light spectrum transmitted through colored shade nets used. Therefore, the objective of this study is to evaluate the effect of colored shade nets on the leaf and root anatomy of the jelly palm plant. The experiment was performed in a completely randomized design, with five treatments, ten replicates and eight plants per replicate, totaling 400 plants. Four colored photo-converter nets with $50 \%$ shading and different radiation proportions were employed: white $\left(985 \mu \mathrm{mol} \cdot \mathrm{m}^{-2} \cdot \mathrm{s}^{-1}\right)$, red $\left(327 \mu \mathrm{mol} \cdot \mathrm{m}^{-2} \cdot \mathrm{s}^{-1}\right)$, black $(433$ $\mu$ mol. $\left.\mathrm{m}^{-2} \cdot \mathrm{s}^{-1}\right)$ and silver $\left(405 \mu \mathrm{mol} . \mathrm{m}^{-2} . \mathrm{s}^{-1}\right)$. The plants cultivated under direct sunlight $\left(1000 \mu \mathrm{mol} \cdot \mathrm{m}^{-2} \cdot \mathrm{s}^{-1}\right)$ were considered as the control group. Leaf and root anatomical analysis was performed on 10 plants per treatment. It is possible to conclude that the colored shade nets caused changes in leaf and root anatomy of the jelly palm plant (Butia capitata).
\end{abstract}

Key words: anatomy, environment, palms, propagation.

\section{INTRODUCTION}

The jelly palm plant [Butia capitata (Martius) Beccari] is a native palm of the Cerrado (neotropical savanna) biome used for many purposes in northern Minas Gerais State, Brazil (Lorenzi et al. 2010). The fruits can be consumed fresh or used to prepare juices, ice cream and popsicles, or processed in the

Correspondence to: Bárbara Nogueira Souza Costa

E-mail: babinogueiraagro@hotmail.com form of a pulp that is widely used and valued in the region (Faria et al. 2008).

Dormancy is common in palm seeds, resulting in slow and uneven germination that may take years to complete (Orozco-Segovia et al. 2003). Germination in Arecaceae is complex due to the anatomical and physiological characteristics of their diaspores, and several types of dormancy have been reported (Orozco-Segovia et al. 2003, Baskin and Baskin 2014) which limit the generation of 
natural populations as well as the commercial cultivation of this species.

The use of colored shade nets can be an appropriate strategy for the fast growth and development of plants. This agricultural technology combines the property of protecting the growth environment with a differential filtering of the solar radiation, which may promote desirable physiological responses regulated by the light (Henrique et al. 2011).

As light is the key resource for photosynthesis, plants acclimate to the light environment under which they are grown to maintain performance and fitness. Acclimation involves altering metabolic processes (including light harvesting and $\mathrm{CO}_{2}$ capture) brought about by a range of mechanisms, from adjustments to leaf morphology to changes in photosynthetic apparatus stoichiometry (Terashima et al. 2006, Kono and Terashima 2014).

The black shade net is considered neutral; it reduces the incident radiation over the plants without influencing the quality of light spectrum. The red shade net reduces the blue, green and yellow light waves by increasing the wave spectrum of red and far red light and with transmittance to wavelengths superior to $590 \mathrm{~nm}$ (Nomura et al. 2009, Costa et al. 2012). The silver shade net (Aluminet ${ }^{\circledR}$ ) changes the property of radiation and increase its reflection, besides permitting temperature control (Polysack Indústrias Ltdas. s. d. 2011). In contrast, the white shade net does not interfere with the light spectrum transferred (Henrique et al. 2011).

Based on the light spectrum transmitted by the nets, it is possible to verify modifications in the standard growth (Macedo et al.2011) and changes in various anatomical, physiological, morphological and biochemical characteristics of plants (Brant et al. 2009). Modifications to leaf anatomy in some plants were observed due to the utilization of colored shade nets, for example in Musa spp. (Silva et al. 2014), Tamarindus indica (Silva et al. 2015) and Malus domestica (Solomakhin and Blanke 2010).

Knowing that colored shade net can alter the anatomical structures of plants, this study was conducted with the objective of evaluating the effect of colored shade net on leaf and root anatomy of the jelly palm plant.

\section{MATERIALS AND METHODS}

The experiment was conducted in the experimental field of the Horticulture Department at the Federal University of Lavras (UFLA). The experimental site was located at $21^{\circ} 14^{\prime} \mathrm{S}$, longitude $45^{\circ} 00^{\prime} \mathrm{W}$ with an altitude of $918 \mathrm{~m}$ a.s.1. According to the climatic classification by Köppen, the climatic condition of the site is CWa (Dantas et al. 2007).

The jelly palm fruits (Butia capitata) were collected from the 2014/15 season in the locality of Mirabela in the north part of the state of Minas Gerais. The pulp was removed manually and driedin the shade for four days. Subsequently were taken to the Plant Tissue Culture Laboratory of the Department of Agriculture, UFLA. The seeds were removed from the endocarp with the help of a table clamp.

The seeds were treated with a fungicide using carboxin-thiram (Vitavax ${ }^{\circledR}$-thiran 200 SC) at its pure concentration and kept for four hoursin the shade. The seeds were then taken to a laminar flow chamber; the operculum was removed from the embryonic cavity and sown in a plastic dish containing a medium texture vermiculate substrate (60 mg) plus $300 \mathrm{ml}$ distilled water. Each dish contained 50 seeds. The dishes were placed in a BOD incubator ata constant temperature of $30^{\circ} \mathrm{C}$ and $80 \%$ relative humidity with a photoperiod of $12 \mathrm{~h}$ for 30 days until full germination. Thereafter,the plants were transferred to pots containing the substrate of distroferric red clay latosoil (characteristic of the region), sand and organic matter in a proportion of $2: 1: 1(\mathrm{v} / \mathrm{v} / \mathrm{v})$ and irrigated periodically. 
The treatments consisted of the utilization of colored shade net ChromatiNET ${ }^{\circledR}$, provided by Polysack Plastic Industry with $50 \%$ shade and different proportions of radiation: white (985 $\mu$ mol. $\left.\mathrm{m}^{-2} \cdot \mathrm{s}^{-1}\right)$, red $\left(327 \mu \mathrm{mol} \cdot \mathrm{m}^{-2} \cdot \mathrm{s}^{-1}\right)$, black (433 $\left.\mu \mathrm{mol} . \mathrm{m}^{-2} . \mathrm{s}^{-1}\right)$ and silver $\left(405 \mu \mathrm{mol} \cdot \mathrm{m}^{-2} \cdot \mathrm{s}^{-1}\right)$. The net was stretched over a wooden structure of $2 \times$ $2 \times 1.5 \mathrm{~m}$ length, width and height, respectively. The plants cultivated with no net and under direct sunlight $\left(1000 \mu \mathrm{mol} . \mathrm{m}^{-2} \cdot \mathrm{s}^{-1}\right)$ were considered as the control group.

After six months, anatomical analysis was performed using 10 plants per treatment. The leaf and root tissue samples were fixed in a $70 \%$ formaldehyde-acetic acid-ethylic ethanol solution (FAA 70\%) (Johansen 1940) for $72 \mathrm{~h}$ and subsequently conserved in $70 \%$ ethanol $(\mathrm{v} / \mathrm{v})$. The transverse sections of leaves and roots were obtained using a table microtome (type LPC). The dermis sections were removed using an steel blade. Tissue from both sections were immersed in a sodium hypochlorite (50\% of active chloride) solution and then washed in distilled water. The transverse sections of leaves were stained with safrablau solution (safranin $0.1 \%$ and astra blue $1 \%$ ); the dermic and transverse sectionsof roots were stained with safranin $1 \%$ solution.Thereafter, the sections were placed in a semi-permanent lamina with glycerinplus water (Kraus and Arduin 1997).

The laminas were examined using an optical microscope (model Olympus BX 60) attached to a microcomputer with an image capturing program and photographed usinga Canon A360 digital camera. The images were analyzed using ImagePro Plus software, with measurement of six fields per replication for each variable analyzed. Within each field, six measurements were taken and the mean values of data were calculated. For the leaf transverse sections, the thickness of parenchyma $(\mu \mathrm{m})$ and epidermis $(\mu \mathrm{m})$ of the adaxial and abaxial side were determined. Root perimeter $(\mathrm{mm})$, thickness of epidermis ( $\mathrm{mm})$ and parenchyma $(\mathrm{mm})$, number of conductor vessels and root area $(\mathrm{mm})$ were determined in the root transverse sections. For the stomatal characterization, the stomatal density (number of stomata per $\mathrm{mm}^{2}$ ) and the polar diameter/equatorial diameter (PD/ED) rate relation were determined using an Olympus CBB microscope and Ken-a-vision 2100 camera.

The experimental design was completely randomized with five treatments, ten replicates and eight plants per replicate, totaling 400 plants. Data were submitted to analysis of variance (ANOVA) using SISVAR (Ferreira 2011) statistical software. The mean values were compared using ScottKnott's test at $5 \%$ probability.

\section{RESULTS AND DISCUSSION}

The leaf of $B$. capitata displayed monostratified epidermis and homogenous mesophyll. However, it was not possible to distinguish the two types of parenchyma in this study. According to Tomlinson et al. (2011) and Sant'anna-Santos et al. (2015), this species has been classified as isobilateral mesophyll. It is likely that, because the plants did not fully develop and the climatic conditions of the study environment were different to conditions to which this species is accustomed, it was not possible to separate the parenchyma safely; this lead us to classify it as homogenous.

Bulliform cells were observed with all treatments (Figure 1). These cells can be an adaptive evolution to a high temperature and radiation environment by providing protection from excess of transpiration during the hot period of the day. Bulliform cells allow leaf rolling which reduces the transpiration area beside various fibers along the leaf limb that are related to tissue support.

The colored shade net promoted a significant difference in the thickness of the epidermis and parenchyma. The plants cultivated under white and silver shade nets and under direct sunlight 


\section{Abaxial epidermis Adaxial epidermis}
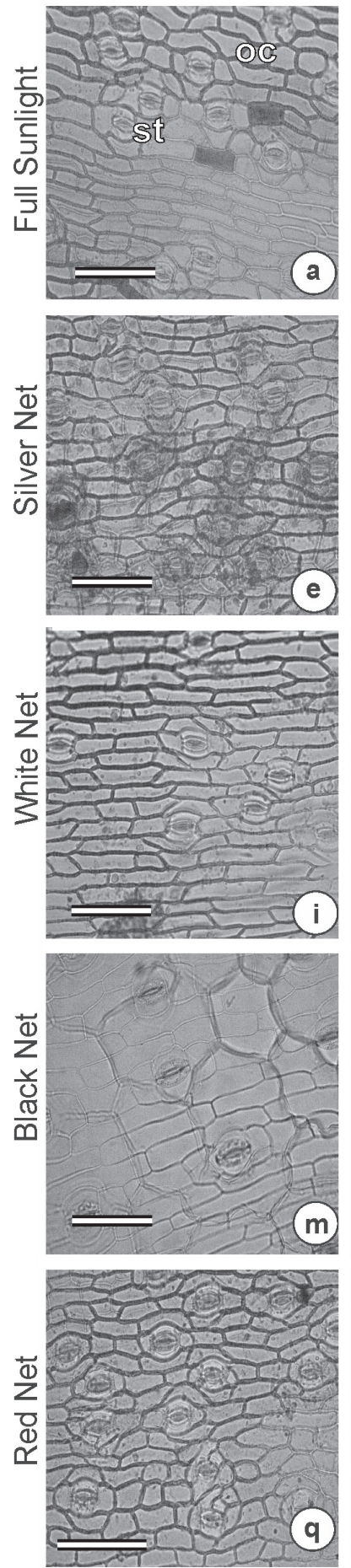
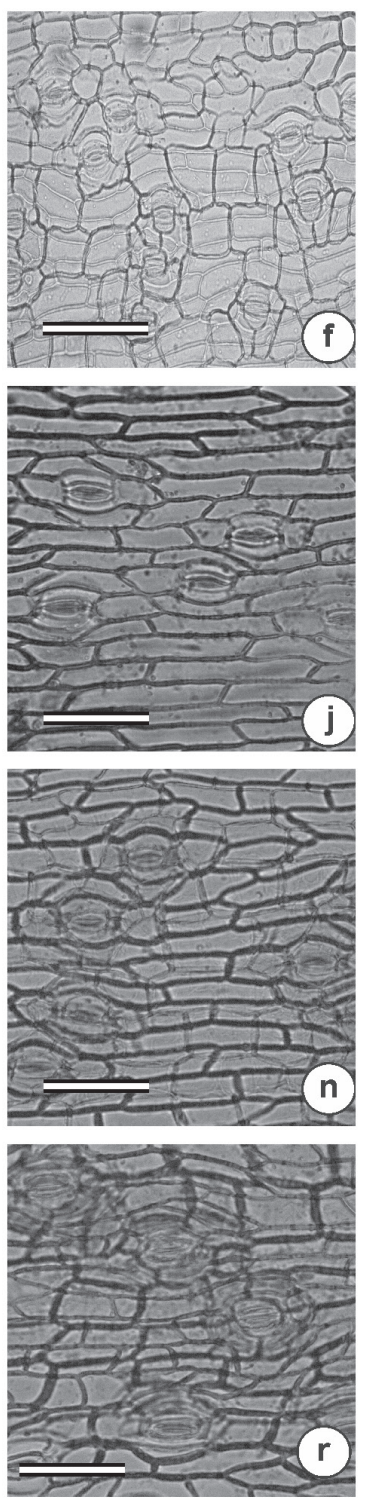

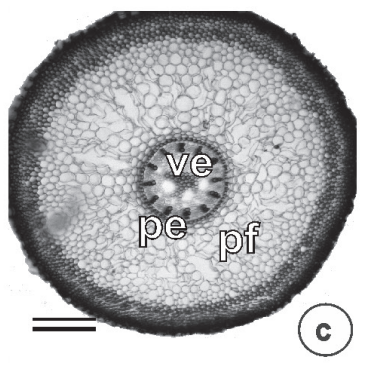

Root
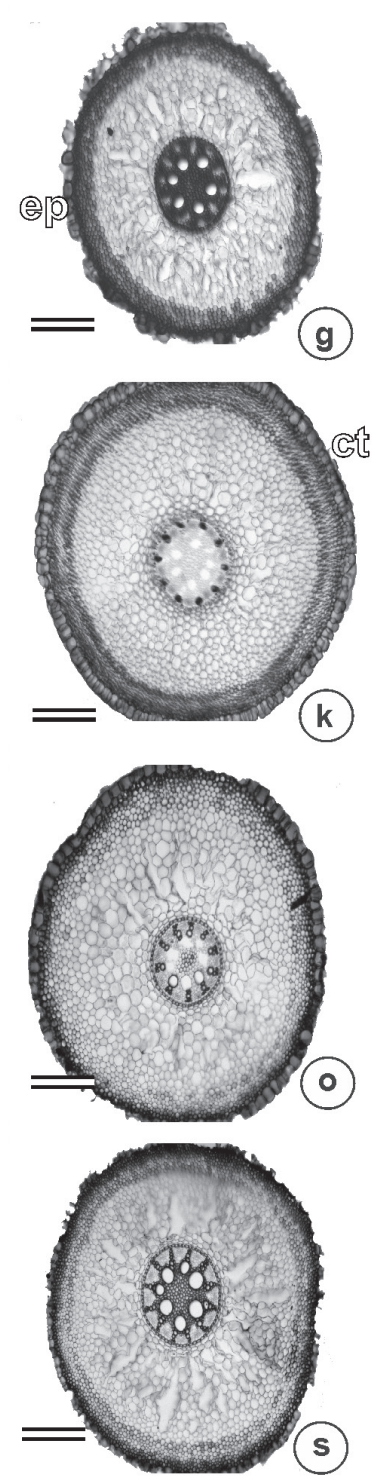

Leaf
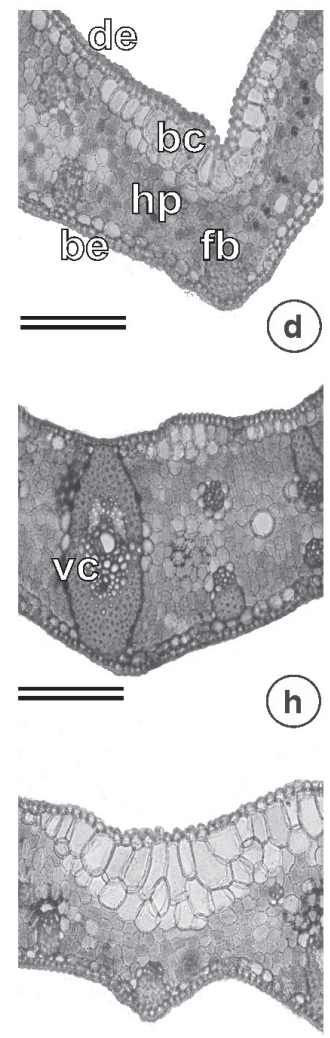

(1)

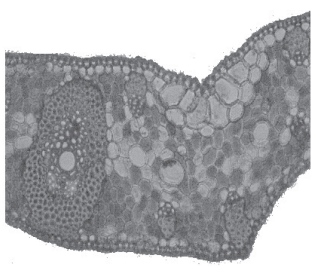

(p)

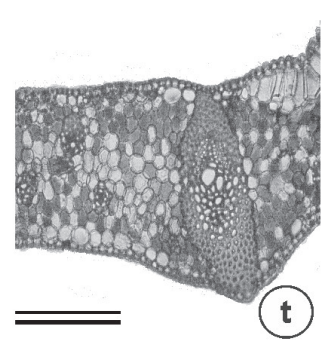

Figure 1 - Photomicrograph of the leaves and roots of jelly palm (Butia capitata) cultivated under different colored shade nets. Section of the adaxial and abaxial epidermis (First and second column); Root cross section (Third column); leaf cross section (Fourth column). a, e, $\mathbf{i}, \mathbf{m}$ and $\mathbf{q}$ (bar $=50 \mu \mathrm{m}) ; \mathbf{b}, \mathbf{f}, \mathbf{j}, \mathbf{n}$ and $\mathbf{r}(\mathrm{bar}=50 \mu \mathrm{m}) ; \mathbf{c}, \mathbf{g}, \mathbf{k}, \mathbf{o}$ and $\mathbf{s}$ (bar $=200 \mu \mathrm{m}) ; \mathbf{d}, \mathbf{h}, \mathbf{l}, \mathbf{p}$ and $\mathbf{t}(\mathrm{bar}=400 \mu \mathrm{m})$. Stomatas (st), ordinary cells $(\mathrm{oc})$, vascular exchange (ve), pericycle (pe), filling parenchyma (fp), adaxial epidermis (de), abaxial epidermis (be), bulliform cells (bc), parenchyma (pa), fiber (fb), epidermis (ep), conductive vessel (cv) and cuticle (ct). 
exhibited greater thickness of parenchyma and epidermal cells of the adaxial leaf side compared to other treatments (Table I).

The leaves of plants cultivated under high light incidence, such as in direct sunlight and using silver shade net, are usually thicker than leaves cultivated under the other shade nets (Brant et al. 2011). High light intensity increases the thickness of abaxial epidermis and parenchyma (Brant et al. 2011, Castro et. al. 2007). The increase in the intensity of light proportionally increases leaf thickness, leaf mass, epidermis and parenchyma thickness and the total number of leaf cells (Dickison 2000). However, Gondim etal. (2008) observed an increase in the epidermis thickness on both sides of the leaf of Colocasia esculenta as the shade intensity increased, in contrast to other tissues analyzed. The plasticity of epidermis is variable in relation to the variation of light intensity which reduces (Gratani et al. 2006) or increases (Morais et al. 2004) according to the level of shading.

According to Shahak et al. (2004) and Taiz and Zeiger (2013), the epidermis is transparent in visible light and its cells possess an external convex wall and lenticular format. In this format it can function as a lens and concentrate the light, thereby the quantity of light that reaches the chloroplast

TABLE I

Thickness of adaxial epidermis (DE), abaxial epidermis (BE) and parenchyma (P) of the leaves of jelly palm plant (Butia capitata) cultivated under colored shade net (Lavras, 2016).

\begin{tabular}{cccc}
\hline \multirow{2}{*}{ Treatments } & DE & BE & P \\
\cline { 2 - 4 } & \multicolumn{3}{c}{$\mu \mathrm{m}$} \\
\hline No net & $0.0169 \mathrm{a}$ & $0.0207 \mathrm{a}$ & $0.2589 \mathrm{a}$ \\
Red & $0.0135 \mathrm{~b}$ & $0.0147 \mathrm{c}$ & $0.1957 \mathrm{~b}$ \\
White & $0.0157 \mathrm{a}$ & $0.0150 \mathrm{c}$ & $0.2316 \mathrm{a}$ \\
Black & $0.0149 \mathrm{~b}$ & $0.0145 \mathrm{c}$ & $0.1683 \mathrm{~b}$ \\
Silver & $0.0173 \mathrm{a}$ & $0.0174 \mathrm{~b}$ & $0.2423 \mathrm{a}$ \\
\hline CV $(\%)$ & 10.66 & 9.97 & 11.57 \\
\hline
\end{tabular}

*The means followed by the same letter in the column found in the same group using the Scott-Knot test at $(p \leq 0.05)$. becomes much higher than in the environment. In the present study, the use of white and silver shade nets or no net resulted in thicker epidermal cells (Table I). As a consequence, less light reached the chloroplasts and the photosynthetic apparatus became more protected against damage caused by excess light, characterized as a factor of anatomical plasticity of epidermis (Taiz and Zeiger 2013). This phenotypic modification has an objective of protecting the chlorophyll of complex antenna from photo oxidation. The increase in the size of the cells in the tissue that constitutes the leaf limb can reduce the arrival of intense light of a wavelength that can mainly affect the photosystem II. In this photosystem is found the D1 protein which is sensitive to excessive light. The photo oxidation can result on the necessity of substitution of this protein affecting directly photosynthesis and productivity of the plant as well as its survival.

Similar results were found in tamarind plants (Tamarindus indica L.) which presented thicker epidermis cells when cultivated under white shade net (Silva et al. 2015). Plants cultivated under direct sunlight showed the greatest thickness of abaxial epidermis when compared to the other treatments. However, among the colored shade nets, the silver one exhibited higher values of this variable (Table I). These results showed high phenotypic plasticity of the leaves, in that the plants exposed to direct sunlight had greater investment in the epidermis, protecting the leaves against water loss,in addition to protecting against photo-oxidation of the chlorophyll and photosystems.

According to Lee et al. (2000), plants maintained under high levels of radiation presented thicker epidermis in one or both sides of the leaf surface. Leaf plasticity is influenced by the change in the thickness, area and other characteristics of the plant due the increase or decrease in the production of primary and secondary metabolites. This thickness enlargement can be an adaptive plant response by reflecting the excessive radiation 
and avoiding water loss and volatilization (Whatley and Whatley 1982, Letchano and Gosselin 1996).

The results reported in this study agree with those of Brant et al. (2010) for Melissa officinalis L. plants, where they found thicker abaxial epidermis in plants cultivated under direct sunlight. Taiz and Zeiger (2013) affirmed that leaves submitted to direct sunlight were thicker and possessed longer parenchymal palisade cells than shaded plants.

Besides, the treatments with no net, or white or silver shade nets also produced thicker parenchyma. This may occur because these two types of nets did not influence the quality of the radiation when compared to the other nets utilized. Consequently, the plants behaved as it they were cultivated in direct sunlight.

In relation to stomatal characteristics, the leaves of the jelly palm had tetracytic type stomata on both sides of the leaf limb, being denominated as amphestomatic leaves according to Sant'annaSantos et al. (2015) (Figure 1). The use of silver net or no net resulted in higher stomatal density on the adaxial surface of the leaf compared to other treatments. The red and black shade nets increased stomatal density on the abaxial face compared to the white shade net. There was no significant difference between treatments in stomatal density on the abaxial surface of the leaf (Table II).

TABLE II

Stomatal density (SD) and polar diameter/ equatorial diameter ratio (PD/ED) of leaves of (Butia capitata) under colored shade nets (Lavras, 2016).

\begin{tabular}{|c|c|c|c|c|}
\hline \multirow{2}{*}{ Treatments } & SD adaxial & SD abaxial & \multirow{2}{*}{$\begin{array}{l}\text { PD/ED } \\
\text { adaxial }\end{array}$} & \multirow{2}{*}{$\begin{array}{l}\text { PD/ED } \\
\text { abaxial }\end{array}$} \\
\hline & \multicolumn{2}{|c|}{ stomata $\mathrm{mm}^{-2}$} & & \\
\hline No net & $224.49 \mathrm{a}$ & $170.85 \mathrm{a}$ & $4.49 \mathrm{a}$ & $3.74 \mathrm{~b}$ \\
\hline Red & $160.98 \mathrm{~b}$ & $194.47 \mathrm{a}$ & $4.48 \mathrm{a}$ & $4.19 \mathrm{a}$ \\
\hline White & $90.41 \mathrm{c}$ & $190.97 \mathrm{a}$ & $4.24 \mathrm{a}$ & $3.41 \mathrm{~b}$ \\
\hline Black & $170.84 \mathrm{~b}$ & $190.85 \mathrm{a}$ & $3.86 \mathrm{~b}$ & $3.99 \mathrm{a}$ \\
\hline Silver & $210.94 \mathrm{a}$ & $184.26 \mathrm{a}$ & $3.64 \mathrm{~b}$ & $3.53 \mathrm{~b}$ \\
\hline CV(\%) & 17.68 & 19.51 & 9.08 & 10.76 \\
\hline
\end{tabular}

* Means followed by the same letter in the column belong in the same group using the Scott-Knott test $(p \leq 0.05)$.
Higher stomatal density is generally related to high stomatal conductance (Justo et al. 2005), preventing inhibition of photosynthesis under adverse conditions (Lima Junior et al. 2006) and increasing the absorption of $\mathrm{CO}_{2}$ which leads to a high photosynthetic rate (Niinemets and Tenhunen 1997).

Our results are in accordance with those of Silva Júnior et al. (2012). These authors reported higher stomatal density on the abaxial face of orchid leaves (Laelia purpurata var. cárnea) grown with no shade net compared to those grown with shade nets. Martins et al. (2009) also found high stomatal density on the abaxial surface of leaves of Ocimum gratissimum plants cultivated in direct sunlight.

Use of silver shade net or no net produced high stomatal density on the abaxial surface of the leaf, representing high phenotypic plasticity in plants with these two treatments (Table II).

The red and white shade nets and no net treatment produced higher $\mathrm{PD} / \mathrm{ED}$ ratio onthe adaxial surface compared to other treatments. In contrast, the PD/ED ratio onthe abaxial surface was higher in plants cultivated with red or black shade net (Table II).

According to Sha Valli Khan et al. (2002), the stomata tend to be elliptic when the $\mathrm{PD} / \mathrm{ED}$ ratio is high, which may result in their high functionality. The variation in the size and the density of the stomata is evidence that plants possess the capacity to rearrange these epidermal structures in response to environmental changes by increasing theiractive involvement in gas exchange and transpiration (Rossatto et al. 2009). Thus, the distinct response found in this study demonstrated the anatomical plasticity of Butia capitata in function of the growing environment.

With regard to root anatomy, the colored shade nets resulted in a significant difference in root perimeter, thickness of epidermis and parenchyma, and root area (Table III). 
The roots exhibited a normal aspect with all treatments, with a well-developed layer of epidermis involving all structures. The parenchymal cells were also well developed with a relatively uniform size from the exterior to the interior. This tissue is characterized as a good means of water storage. The external root cell wall was thicker, characterizing its function as protection against possible aggression originating from the soil (Figure 1).

Plants cultivated under the white shade net presented a larger root perimeter, thicker epidermis and larger root area compared to other treatments. Red and black shade net produced larger root perimeter and root area compared to direct sunlight or silver shade net. Treatment with no net produced high values for the same characters asthe black shade net (Table III). No significant differences were observed between treatments in relation to pericycle perimeter and number of conductor vessels. The greater thickness of the epidermis under white shade net, followed by black shade net, indicated that the reduction of light incidence could positively affect this characteristic. Lower radiation possibly resulted in lower environmental temperature. Therefore, the root could develop without being under high stress. Also, the soil around the roots was less affected by loss of water since it received less radiation which resulted in better development of the epidermis.
Anatomical changes in the roots still need to be investigated as few mechanisms which can explain root growth in the field are known and given that roots are exposed to diverse soil condition within space and time. The root system develops according to genetic parameters.However, the soil conditions where the root grows can also influence it (Rich and Watt 2013), which may explain the difference found in some anatomical characteristics of the root with some of the treatments. Considering that root has direct contact with the soil, the distinct shade nets used in this study can lead to a difference in soil temperature by affecting the physicochemical properties of water (Willing and Leopold 1983) and, therefore, cause changes in the roots.

The reduction in temperature resulting from the use of nets with greater light blocking capacity can interfere with the biological properties of the cell membrane. Tissue expansion at low temperatures can cause lesions in the cell membranedue to the reduced elasticity, which can cause anatomical modification of the roots. In addition, the soil temperature directly affects root growth, metabolism and transport and indirectly affects the aerial parts of the plant. Studies with controlled environmental conditionshave shown that the root grows faster at higher temperatures up to certain limit (Gregory 2006). Once root elongation rate increases with the increase in temperature, a higher rate of cellular division can be observed to result

TABLE III

Root perimeter (RP), pericycle perimeter (PP), thickness of epidermis (TE), thickness of parenchyma (TP), root area and number of conductors vessels (NCV) of (Butia capitata) under colored shade net (Lavras, 2016).

\begin{tabular}{cccccccc}
\hline \multirow{2}{*}{ Treatments } & RP & PP & TE & TP & AREA & $\begin{array}{c}\text { NCV } \\
\text { (un) }\end{array}$ \\
\cline { 2 - 7 } & & & Mm & & $0.4095 \mathrm{a}$ & $1.0343 \mathrm{c}$ & $12.0000 \mathrm{a}$ \\
\hline No net & $3.3041 \mathrm{c}$ & $0.9133 \mathrm{a}$ & $0.0358 \mathrm{c}$ & $0.0305 \mathrm{c}$ & $0.3991 \mathrm{a}$ & $1.1748 \mathrm{~b}$ & $12.3333 \mathrm{a}$ \\
Red & $3.8408 \mathrm{~b}$ & $1.0114 \mathrm{a}$ & $1.0204 \mathrm{a}$ & $0.0599 \mathrm{a}$ & $0.4222 \mathrm{a}$ & $1.2945 \mathrm{a}$ & $10.0000 \mathrm{a}$ \\
White & $4.0322 \mathrm{a}$ & $1.0153 \mathrm{a}$ & $0.0443 \mathrm{~b}$ & $0.4199 \mathrm{a}$ & $1.1727 \mathrm{~b}$ & $11.0000 \mathrm{a}$ \\
Black & $3.8373 \mathrm{~b}$ & $1.0587 \mathrm{a}$ & $0.0361 \mathrm{c}$ & $0.3196 \mathrm{~b}$ & $0.8687 \mathrm{~d}$ & $12.3333 \mathrm{a}$ \\
Silver & $3.2998 \mathrm{~d}$ & 9,01 & 8.54 & 2.42 & 5.01 & 7.99 \\
\hline CV(\%) & 2.68 & &
\end{tabular}

*Means followed by the same letter in the column belongs in the same group by Scott-Knott test $(p \leq 0.05)$. 
in small cells. Moreover, positive and negative correlation between temperature and root diameter have already been described, showing that the temperature can affect the root diameter (Macduff and Hopper 1986, Pahlavanian and Silk 1988) or,in some cases, may not affect it (Abbas Al-Ani and Hay 1983).

The soil condition strongly influenced the root architecture due to impedance (physical stress), which reduces the elongation rate and affects water, oxygen and nutrient availability (Gliński and Lipiec 1990, Gregory 2006). Roots of maize grown at temperatures above $24^{\circ} \mathrm{C}$ had reduced total biomass (Nagel et al. 2009), which indicates less investment in biomass. However, the effect of soil temperature on roots and how this interaction can affect root anatomy is still not well understood. This subject provides a vast field for study in the future.

\section{CONCLUSIONS}

Use of no net, or white or silver shade nets resulted in high investment in the enlargement of epidermal and parenchymal cells due to the effect of stressful conditionson plants.

Use of silver shade net or no net resulted in greater stomatal density in the adaxial surface of the leaf. Red shade net produced higher PD/ ED relation on both leaf surfaces.This means that the stomata tend to be elliptical, resulting in high functionality of the stomata. Therefore, the quality of the stomata is more important than their quantity.

The white shade net improved the anatomical characteristics of roots of Butia capitata.

The red shade produced better anatomical characteristics compared to the other shade nets or no net. Therefore, this shade net is the most indicated for growth of Butia capitata.

\section{ACKNOWLEDGMENTS}

The authors thank the Coordenação de Aperfeiçoamento de Pessoal de Nível Superior
(CAPES), Conselho Nacional de Desenvolvimento Científico e Tecnológico (CNPq) and Fundação de Amparo à Pesquisa do Estado de Minas Gerais (FAPEMIG) for providing financial support for the execution of the experiment.

\section{REFERENCES}

ABBAS AL-ANI MK AND HAY RKM. 1983. The influence of growing temperature on the growth and morphology of cereal seedling root systems. J Exp Bot 34: 1720-1730.

BASKIN CC AND BASKIN JM. 2014. Seeds: Ecology, Biogeography and Evolution of Dormancy and Germination. (2nd edn) Academic Press, San Diego.

BRANT RS, PINTO JEBP, ROSA LF, ALBUQUERQUE CJB, FERI PH AND CORRÊA RM. 2009. Crescimento, teor e composição do óleo essencial de melissa cultivada sob malhas fotoconversoras. Ciênc Rural 39: 1401-1407.

BRANT RS, PINTO JEBP, ROSAL LF, ALVES C, OLIVEIRA C AND ALBUQUERQUE CJB. 2011. Adaptações fisiológicas e anatômicas de Melissa officinalis L. (Lamiaceae) cultivadas sob malhas termorrefletoras em diferentes intensidades luminosas. Rev Bras Plantas Med 13: 467-474.

BRANT RS, PINTO JEBP, ROSAL LF, CASTRO EM, OLIVEIRA C AND ALBUQUERQUE CJB. 2010. Características fisiológicas e anatômicas de Melissa officinalis cultivadas sob diferentes condições de luminosidade. Magistra 22: 146-152.

CASTRO EM, PINTO JEBP, SOARES AM, MELO HC, BERTALUCCI SKV, VIEIRA CV AND JÚNIOR ECL. 2007. Adaptações anatômicas de folhas de Mikania glomerata Sprengel (Asteraceae), em três regiões distintas da planta, em diferentes níveis de sombreamento. Rev Bras Plantas Med 9: 8-16.

COSTAAG, CHAGAS JH, PINTO JEBP AND BERTOLUCCI SKV. 2012. Crescimento vegetativo e produção de óleo essencial de hortelã-pimenta cultivada sob malhas. Pesq Agropec Bras 47: 534-540.

DANTAS AAA, CARVALHO LG AND FERREIRA E. 2007. Classificação e tendência climática em Lavras, MG. Ciênc Arotec 31: 1862-1866.

DICKISON WC. 2000. Integrative plant anatomy. Academic Press.

FARIA JP, ALMEIDA F, SILVA LCR, VIEIRA RF AND AGOSTINI-COSTA TS. 2008. Caracterização da polpa do coquinho-azedo (Butia capitata var capitata). Rev Bras Frut 30: 827-829.

FERREIRA DF. 2011. Sisvar: a computer statistical analysis system. Ciênc Agrotec 35: 1039-1042.

GLIŃSKIJ AND LIPIEC J. 1990. Soil physical conditions and plant roots. Boca Raton, FL: CRC Press. 
GONDIM ARO, PUIATTI M, VENTRELLA MC AND CECON PR. 2008. Leaf plasticity in taro plants under different shade conditions. Bragantia 67: 1037-1045.

GRATANI L, COVONE F AND LARCHER W. 2006. Leaf plasticity in response to light of three evergreen species of the Mediterranean maquis. Trees 20: 549-558.

GREGORY PJ. 2006. Roots, rhizosphere and soil: the route to a better understanding of soil science? Eur J Soil Sci 57: 2-12.

HENRIQUE PC, ALVES JG, DEUNER S, GOULART PFP AND LIVRAMENTO DE. 2011. Aspectos fisiológicos do desenvolvimento de mudas de café cultivadas sob telas de diferentes colorações. Pesq Agropec Bras 46: 458-465.

JOHANSEN DA. 1940. Plant Microtechnique. New York: McGraw Hill, First ed., 523 p.

JUSTO CF, SOARES ÂM, GAVILANES ML AND CASTRO EMD. 2005. Leaf anatomical plasticity of Xylopia brasiliensis Sprengel (Annonaceae). Acta Bot Bras 19: 111-123.

KONO M AND TERASHIMA I. 2014. Long-term and shortterm responses of the photosynthetic electron transport to fluctuating light. J Photochem Photobiol B 137: 89-99.

KRAUS JE AND ARDUIN M. 1997. Manual básico de métodos em morfologia vegetal. Rio de Janeiro: Seropédica: Edur., 198 p.

LEE DW, OBERBAUER SF, JOHNSON P, KRISHNAPILAY B, MANSOR M, MOHAMAD H AND YAP SK. 2000. Effects of irradiance and spectral quality on leaf structure and function in seedlings of two Southeast Asian Hopea (Dipterocarpaceae) species. Am J Bot 87: 447-455.

LETCHANO W AND GOSSELIN A. 1996. Transpiration essential oil gland, epicuticular wax, and morphology of Thymus vulgaris are influenced by light intensity and water supply. J Hortic Sci 71: 123-134.

LIMA JUNIOR EC, ALVARENGA AAD, CASTRO EMD, VIEIRA CV AND BARBOSA JPRAD. 2006. Aspectos fisioanatômicos de plantas jovens de Cupania vernalis Camb. submetidas a diferentes níveis de sombreamento. Rev Árvore 30: 33-41.

LORENZI H, NOBLICK LR, KAHN F AND FERREIRA E. 2010. Flora Brasileira Lorenzi: Arecaceae (Palmeiras). Plantarum, Nova Odessa.

MACDUFF JH AND HOPPER MJ. 1986. Effects of root temperature on uptake of nitrate and ammonium ions by barley grown in flowing-solution culture. Plant Soil 91: 303-306.

MACEDO AF, LEAL-COSTA MV, TAVARES ES, LAGE CLS AND ESQUIBEL MA. 2011. The effect of light quality on leaf production and development of in vitro-cultured plants of Alternanthera brasiliana Kuntze. Environ Exp Bot 70: 43-50.

MARTINS JR, ALVARENGA AA, CASTRO EM, SILVA APO, OLIVEIRA C AND ALVES E. 2009. Anatomia foliar de plantas de alfavaca-cravo cultivadas sob malhas coloridas. Ciênc Rural 39: 82-87.

MORAIS H, MEDRI ME, MARUR CJ, CARAMORI PH, RIBEIRO AMA AND GOMES JC. 2004. Modifications on leaf anatomy of Coffea arabica caused by shade of pigeonpea (Cajanus cajan). Braz Arch Biol Technol 47: 863-871.

NAGEL KA ET AL. 2009. Temperature responses of roots: impact on growth, root system architecture and implications for phenotyping. Funct Plant Biol 36: 947-959.

NIINEMETS U AND TENHUNEN JD. 1997. A model separating leaf structural and physiological effects on carbon gain along light gradients for the shade-tolerant species Acer saccharum. Plant Cell Environ 20: 845-866.

NOMURA ES, LIMA JD, RODRIGUES DS, GARCIA VA, FUZITANIL EJ AND SILVA SHM. 2009. Crescimento e produção de antúrio cultivado sob diferentes malhas de sombreamento. Ciênc Rural 39: 1394-1400.

OROZCO-SEGOVIA A, BATIS AI, ROJAS-ARECHIGA M AND MENDOZA A. 2003. Seed biology of palms: a review. Palms 47: 79-94.

PAHLAVANIAN AM AND SILK WK. 1988. Effect of temperature on spatial and temporal aspects of growth in the primary maize root. Plant Physiol 87: 529-532.

POLYSACK INDÚSTRIAS LTDA. S.D. 2011. Malhas termorefletorasaluminizadas. Disponível em: $<$ http:// www.polysack.com>.

RICH SM AND WATT M. 2013. Soil conditions and cereal root system architecture: review and considerations for linking Darwin and Weaver. J Exp Bot 64: 1193-1208.

ROSSATTO DR, HOFFMANN WA AND FRANCO AC. 2009. Características estomáticas de pares congenéricos de cerrado e mata de galeria crescendo numa região transicional no Brasil central. Acta Bot Bras 23: 499-508.

SANT'ANNA-SANTOS BF, CARVALHO JUNIOR WGO AND AMARAL VB. 2015. Butia capitata (Mart.) Becc. lamina anatomy as a tool for taxonomic distinction from $B$. odorata (Barb. Rodr.) Noblick comb.nov (Arecaceae). An Acad Bras Cienc 87: 71-81.

SHA VALLI KHAN PS, KOZAI T, NGUYEN QT, KUBOTA C AND DHAWANV. 2002. Growth and net photosynthetic rates of Eucalyptus tereticornis Smith under photomixotrophic and various photoautotrophic micropropagation conditions. Plant Cell Tiss Org 71: 141146.

SHAHAK Y, GUSSAKOVSKY EE, GAL E AND GANELEVIN R. 2004. ColorNets: crop protection and light-quality manipulation in one technology. Acta Hortic 659: 143-151.

SILVA RAL, MADALI RH, PIO LS, RODRIGUES FA, PASQUAL MAND DE CASTRO EM. 2014. Leaf anatomy of genotypes of banana plant grown under coloured shade nets. Afr J Biotechnol 23: 2359-2366. 
SILVA RAL, SOARES JDR, DIAS GDMG, PASQUAL M, CHAGAS EA AND GAVILANES ML. 2015. Cultivo de tamarindo sob malhas coloridas: plasticidade anatômica foliar. Ciênc Rural 45: 238-244.

SILVA JÚNIOR JM, CASTRO EM, RODRIGUES M, PASQUAL M AND BERTOLUCCI SKV. 2012. Variações anatômicas de Laelia purpurata var. cárnea cultivada in vitro sob diferentes intensidades e qualidade spectral de luz. Ciênc Rural 42: 480-486.

SOLOMAKHIN AAND BLANKE M. 2010. The microclimate under coloured hailnets affects leaf and fruit temperature, leaf anatomy, vegetative and reproductive growth as well as fruit colouration in apple. Ann Appl Biol 156: 121-136.
TAIZ L ANDZEIGER E. 2013. Fisiologia vegetal. 5a ed., Porto Alegre: Artmed, $918 \mathrm{p}$.

TERASHIMA I, HANBA YT, TAZOE Y, VYAS P AND YANO S. 2006. Irradiance and phenotype: comparative eco-development of sun and shade leaves in relation to photosynthetic $\mathrm{CO}_{2}$ diffusion. J Exp Bot 57: 343-354.

TOMLINSON PB, HORN JW AND FISHER JB. 2011. The anatomy of palms. Clarendon Press, Oxford, $276 \mathrm{p}$.

WHATLEY FH AND WHATLEY FR. 1982. A luz e a vida das plantas. São Paulo: EPU-EDUSP, 101 p.

WILLING RP AND LEOPOLD AC. 1983. Cellular expansion at low temperature as a cause of membrane lesions.Plant Physiol 71: 118-121. 